\title{
SPOLECZNE DETERMINANTY AKTYWNOŚCI TURYSTYCZNEJ STUDENTÓW KRAKOWSKIEGO OŚRODKA AKADEMICKIEGO
}

\begin{abstract}
Artykuł porusza problematykę aktywności turystycznej. Zajmuje ona bowiem istotne miejsce wśród badań, które mają na celu poznanie reguł i mechanizmów rządzących rynkiem turystycznym. Dokonano krótkiego przeglądu klasyfikacji grup determinant aktywności turystycznej i wskazano na najważniejsze egzogenne uwarunkowania (ekonomiczne, demograficzne i społeczne).

Celem niniejszego opracowania było określenie wpływu wybranych czynników społecznych na poziom aktywności turystycznej studentów. Zanalizowano wpływ rodziny, szkoły oraz wybranych organizacji o charakterze turystycznym. Szczególnie interesujące było sprawdzenie, czy uprawianie turystyki z rodzicami w wieku dziecięcym i okresie dorastania determinuje jej poziom u człowieka dorosłego. Postawiono hipotezę (H1) o występowaniu istotnej zależności między wybranymi czynnikami społecznymi a poziomem aktywności turystycznej studentów krakowskiego ośrodka akademickiego. Badania przeprowadzono z wykorzystaniem metody sondażu diagnostycznego. Do zbierania danych posłużył kwestionariusz ankiety. Badaniami zostali objęci studenci drugiego roku studiów stacjonarnych pierwszego stopnia losowo wybranych kierunków uczelni krakowskich (438 osób). Analiza statystyczna oparta na metodach statystycznych (test niezależności chikwadrat, współczynnik zbieżności T-Czuprowa) pozwoliła na wykrycie kilku prawidłowości w badanej zbiorowości.

Badania pokazały, że czynniki społeczne odgrywają znaczącą rolę w procesie kształtowania się aktywności turystycznej i w faktycznym uczestnictwie w turystyce osób w badanym przedziale wiekowym. Wyniki badań pokazały, że częstość wyjazdów turystycznych z rodzicami, jest tym czynnikiem o charakterze społecznym, który wywiera najsilniejszy wpływ na aktywność turystyczną studentów w krakowskim ośrodku akademickim.
\end{abstract}

Słowa kluczowe: turystyka studencka, aktywność turystyczna, społeczne determinanty aktywności turystycznej, studenci.

\section{WSTĘP}

W ostatnich latach umacnia się znaczenie turystyki we współczesnym społeczeństwie. Poprawa standardu życia i możliwości swobodnego przemieszczania się przyczyniły się do podróżowania milionów nowych turystów. Wśród nich na szczególną uwagę zasługują ludzie młodzi (studiujący), którzy należą do najbardziej aktywnych w tym zakresie. Młodzież uniwersytecka dysponuje dużą ilością czasu wolnego, jest już względnie wykształcona i predysponowana do pełnienia ról kierowniczych w wielu dziedzinach życia i odważnie podejmuje wyzwania współczesnego świata. Także sam tryb życia

${ }^{1}$ Dr Anna Delekta, Zakład Turystyki i Badań Regionalnych, Instytut Geografii, Uniwersytet Pedagogiczny w Krakowie, ul. Podchorążych 2, 30-084 Kraków, tel. (012) 662 6260, e-mail: adelekta@up.krakow.pl 
studenckiego wznieca naturalną potrzebę podróżowania. Przyglądanie się turystyce studentów pozwala odpowiedzieć na wiele nurtujących pytan, dotyczących obecnych wyjazdów turystycznych, ich częstotliwości, preferowanych rodzajów turystyki, motywów wyjazdów, sposobów organizacji wyjazdu, destynacji turystycznych i innych. Pozwala także określić wpływ wielu czynników determinujących poziom aktywności turystycznej ze szczególnym uwzględnieniem czynników społecznych.

Zakładając, że obecni studenci są i będą jedną z najbardziej aktywnych turystycznie grup i w ciagu najbliższej dekady będą głównymi odbiorcami usług turystycznych, zdiagnozowanie poziomu aktywności turystycznej oraz uwarunkowań uprawiania turystyki przez tę właśnie grupę społeczną może być ekonomicznie i społecznie bardzo pożyteczne.

Praca ma na celu sprawdzenie, czy w badanej populacji studentów czynniki społeczne wywierają istotny wpływ na poziom uczestnictwa w turystyce.

\section{MATERIAŁ I METODA}

Badania prezentowane w niniejszej pracy stanowią część projektu badawczego, którego celem jest obserwowanie stanu aktywności turystycznej młodzieży studiującej w największych polskich ośrodkach akademickich oraz poszukiwanie $\mathrm{i}$ analizowanie czynników ją determinujących. Badania te koncentrują się na poszukiwaniu i analizie wielu grup czynników, jednakże w tej pracy zajęto się sprawdzeniem jedynie wybranych czynników społecznych.

Część empiryczną badań zrealizowano z wykorzystaniem sondażu diagnostycznego przeprowadzonego metodą reprezentatywną wśród populacji studentów wybranych losowo kierunków uczelni państwowych Krakowa. Badania przeprowadzono od marca do czerwca 2014 roku. Próba badawcza wyniosła 438 osób. Założono, że badaną populację będą stanowili studenci studiujący na drugim roku studiów stacjonarnych pierwszego stopnia. Założenie to jest skutkiem prowadzonej obserwacji, która pozwala sądzić, że studenci drugiego roku są już odpowiednio zaadaptowani na uczelni, znają ofertę skierowaną do nich ze strony uczelni (również turystyczna), są członkami nowych grup rówieśniczych, dysponują dość dużą ilością czasu wolnego (wynikającego z organizacji roku akademickiego) i jednocześnie nie są jeszcze pochłonięci pisaniem prac dyplomowych. Są to osoby, które świadomie podejmują działania w zakresie turystyki, często są również inicjatorami takich działań.

$\mathrm{Na}$ etapie analizy statystycznej uzyskanych wyników zastosowano nieparametryczny test niezależności chi-kwadrat, który pozwala na określenie istotności zależności między zmiennymi mierzonymi na skali nominalnej. Przyjęto - podobnie jak w większości opracowań z tego zakresu - założenie, że wynik istotny statystycznie to taki, dla którego wartość „p” jest mniejsza niż 0,05 . Zastosowano również współczynnik zbieżności TCzuprowa służący do mierzenia siły związku między zmiennymi.

\section{ROZUMIENIE AKTYWNOŚCI TURYSTYCZNEJ}

Podstawową cechą istot żywych oraz sposobem ich istnienia jest aktywność. To stan przeciwny bierności i stan normalny dla człowieka. Wpływy zewnętrzne moga powodować jedynie modyfikację aktywności. Łopaciński uważa, że ,[...] aktywność jednostki należy rozumieć jako pewne kontinuum zawarte pomiędzy zespołem zachowań nakierowanych na zmiany $\mathrm{w}$ otoczeniu $\mathrm{i} w$ sobie, a biernym poddaniem się wpływowi otoczenia $\mathrm{i}$ ewentualnie zachodzącym $\mathrm{w}$ nim zmianom oraz 
konserwatyzmem wewnętrznym",2. W klasyfikacji aktywności ludzkiej dokonanej przez Skornego ${ }^{3}$ wyróżniono takie rodzaje aktywności człowieka, jak: społeczna, produkcyjna, samoobsługowa, edukacyjna, zabawowa, militarna, kulturalna, artystyczna, naukowa i turystyczna.

Aktywność turystyczna to ,całokształt czynności związanych z przygotowaniem i uprawianiem turystyki oraz różnymi formami jej przeżywania"4. Jednakże najważniejszym przejawem aktywności turystycznej jest samo uprawianie turystyki, dlatego badania naukowe koncentrują się głównie na analizie podróży faktycznie odbytej (podróży przeżywanej), pomijając podróż wyobrażoną (przed wyjazdem) i podróż przedłużoną (po powrocie), które w myśl koncepcji Łopacińskiego ${ }^{5}$ i Boyera ${ }^{6}$ są również przejawami aktywności turystycznej. Podobnie uważa Alejziak, który doprecyzował definicję Łopacińskiego i podaje, że aktywność turystyczna to „ogół czynności i działań ludzi związanych $\mathrm{z}$ ich uczestnictwem $\mathrm{w}$ turystyce. W odniesieniu do konkretnych wyjazdów jest to proces zaczynający się na długo, zanim nastąpi dany wyjazd, oraz trwający jeszcze pewien czas po powrocie ${ }^{7}$. Ten sam autor dostrzega potrzebę rozróżnienia aktywności turystycznej w szerokim i w wąskim znaczeniu.

W szerokim rozumieniu pojęcie to odnosi się do „ogółu zachowań ludzi, związanych z ich uczestnictwem w różnych formach turystyki”»" W wąskim znaczeniu aktywność turystyczna odnosi się do samego uczestnictwa człowieka w turystyce. W tym znaczeniu aktywność turystyczna odbywa się tylko w czasie wyjazdu i zanika w momencie powrotu turysty do miejsca stałego zamieszkania. Pisząc o aktywności turystycznej w empirycznej części tej pracy, uwzględniono wąskie ujęcie tego problemu. Takie ujęcie pozwala na analizę poziomu, struktury i dynamiki uczestnictwa w turystyce badanej populacji oraz analizę czynników, które determinują to zjawisko.

\section{UWARUNKOWANIA UCZESTNICTWA W TURYSTYCE}

Uprawianie turystyki jest zachowaniem nabytym w procesie socjalizacji, przejętym od otoczenia kulturowego i tym samym jest uwarunkowane wieloma czynnikami, które mają wpływ na jej poziom i strukturę. W literaturze przedmiotu istnieje wiele klasyfikacji i typologii uwarunkowań aktywności turystycznej. Najczęściej skupiają się one na klasyfikowaniu poszczególnych czynników na grupy. Jedlińska9 ${ }^{9}$ podzieliła determinanty zachowań konsumenckich turystów na uwarunkowania zewnętrzne oraz uwarunkowania wewnętrzne. Na czynniki z pierwszej grupy składają się trzy podgrupy: czynniki

\footnotetext{
${ }^{2}$ K. Łopaciński, Poziom aktywności turystycznej studentów, [w:] Społeczno-pedagogiczne problemy turystyki, red. J.A. Malinowski, Instytut Turystyki, Warszawa 1988, s. 116.

3 Z. Skorny, Mechanizmy regulacyjne ludzkiego działania, Wydawnictwo Naukowe PWN, Warszawa 1989.

${ }^{4}$ K. Łopaciński, Aktywność turystyczna młodzieży akademickiej, „Problemy Turystyki” 1986/2, s. 117.

5 Ibidem.

${ }^{6}$ Boyer M., Le tourisme, Presses Universitaires de Lyon, Lyon 1999, s. 167.

7 W. Alejziak, Determinanty i zróżnicowanie społeczne aktywności turystycznej, Wydawnictwo AWF, Kraków 2009, s. 25.

${ }^{8}$ Ibidem.

9 M. Jedlińska, Specyfika zachowań konsumenckich na rynku turystycznym, [w:] Turystyka w badaniach naukowych, red. A. Nowakowska, M. Przydział, Prace ekonomiczne, WSiZ, Rzeszów 2006.
} 
ekonomiczne, społeczno-kulturowe i regionalne. Do grupy czynników społecznokulturowych zalicza ona między innymi wpływ grup odniesienia i wpływ szeroko rozumianej kultury, która kształtuje sposób spędzania wolnego czasu. Zawadzki ${ }^{10}$ wskazuje na oddziaływanie wychowawcze rodziny, szkoły, grupy rówieśniczej, środków masowego przekazu jako czynniki wpływające na występowanie potrzeby wypoczynku połączonego z wyjazdem. Również Bomirska i innil ${ }^{11}$ wyróżniają obok czynników ekonomicznych i demograficznych właśnie czynniki społeczne (wpływ środowiska społecznego). Podobnie Wartecka-Ważyńska ${ }^{12}$ wskazuje społeczne, ekonomiczne i organizacyjno-instytucjonalne uwarunkowania uprawiania turystyki.

Po dokonaniu tego krótkiego przeglądu klasyfikacji grup determinant aktywności turystycznej można zaobserwować, że większość z nich uwzględnia grupę czynników społecznych. O tym, jak duże znaczenie dla ukształtowania się właściwej postawy wobec turystyki i uczestnictwa w niej, ma ta grupa czynników pisali między innymi Denek ${ }^{13}$, Kaczmarek i inni ${ }^{14}$, Marcinkowski ${ }^{15}$, Wartecka-Ważyńska ${ }^{16}$, Różycki ${ }^{17}$, Alejziak ${ }^{18}$.

Ważną grupą czynników warunkujących udział w turystyce są czynniki, które można określić jako wewnętrzne. Należą do nich między innymi potrzeby turystyczne, motywy podejmowania tego typu aktywności, postawy, aspiracje. Jednak analiza relacji tych czynników z aktywnością turystyczną stanowi materiał na inne opracowanie.

W niniejszym artykule zajęto się analizą następujących czynników społecznych determinujących aktywność turystyczną studentów: przynależnością do organizacji turystycznych, aktywnością turystyczną rodziny badanego, aktywnością szkół (do których uczęszczał badany przed podjęciem studiów) w zakresie organizacji turystyki.

\section{WPEYW ŚRODOWISK WYCHOWAWCZYCH NA AKTYWNOŚĆ TURYSTYCZNĄ}

Środowisko wychowawcze jest częścią obiektywnego środowiska społecznego człowieka (łącznie z jego podłożem przyrodniczym i kontekstem kulturowym). Tworzą je osoby, grupy społeczne i instytucje pełniące zadania wychowawcze, zachęcające jednostki i grupy (dzieci, młodzież i dorosłych) do przyswajania wartości moralnych i

\footnotetext{
10 M. Zawadzki, Metody badania uczestnictwa mieszkańców Polski w podróżach, „Problemy Turystyki” 1993/3.

11 L. Bomirska, G. Gawlak-Kica, E. Kraśnicki, Społeczno-ekonomiczne bariery uczestnictwa młodzieży szkolnej $i$ studiujacej $w$ turystycznych formach rekreacji, [w:] Wyznaczniki i bariery uczestnictwa $w$ turystycznych formach rekreacji, red. S. Wykrętowicz, Wydawnictwo AWF, Warszawa 1988.

12 A. Wartecka-Ważyńska, Turystyka młodzieży i jej uwarunkowania, Wydawnictwo Naukowe UAM, Poznań 2007.

${ }^{13}$ K. Denek, W kręgu edukacji, krajoznawstwa i turystyki w szkole, Eruditus, Poznań 2000.

${ }^{14}$ J. Kaczmarek, A. Stasiak, B. Włodarczyk, Produkt turystyczny albo jak organizować poznawanie świata, Wydawnictwo Uniwersytetu Łódzkiego, Łódź 2002.

${ }^{15}$ M. Marcinkowski, Zachowania wolnoczasowe wskaźnikiem jakości życia, [w:] Czas wolny. Rekreacja. Turystyka. Hotelarstwo. Żywienie, red. W. Siwiński, R.D. Tauber, E. Mucha-Szajek, Wydawnictwo Wyższej Szkoły Hotelarstwa i Gastronomii w Poznaniu, Poznań 2003.

${ }^{16}$ A. Wartecka-Ważyńska, Rola wybranych organizacji społecznych $w$ ksztattowaniu aktywności turystycznej młodzieży, „Turystyka i Hotelarstwo” 2005/8.

${ }^{17}$ P. Różycki, Determinanty aktywności turystycznej mtodzieży, „Problemy Turystyki” 2006/1-4.

${ }^{18}$ W. Alejziak, op. cit.
} 
zgodnych z nimi zachowań społecznych, odpowiadających ideałowi wychowawczemu społeczeństwa $^{19}$. Ze względu na zamiar (intencję) oddziaływań na osobowość człowieka w procesie jego wychowania i socjalizacji, można wyodrębnić dwa rodzaje środowisk: naturalne i intencjonalne ${ }^{20}$. Naturalne środowisko wychowawcze to na przykład rodzina, grupa rówieśnicza czy środowisko lokalne. Jednostka staje się częścią tego środowiska ze względu na miejsce urodzenia, przedział wieku czy więzy krwi. Środowisko to wpływa na człowieka zazwyczaj spontanicznie i w niezamierzony sposób. Intencjonalnym środowiskiem wychowawczym określa się natomiast środowisko społeczne celowo powołane do oddziaływania wychowawczego na osobowość jednostki w procesie wychowania i socjalizacji oraz do organizowania tego procesu. Najważniejszym środowiskiem tego typu jest szkoła.

Każdy człowiek żyje i funkcjonuje w środowisku wychowawczym (zazwyczaj w kilku równolegle) i podlega jego różnorodnym wpływom. Środowiska te odgrywają ogromną rolę w kształtowaniu postaw człowieka, w tym postawy wobec czynności wolnoczasowych, do których zalicza się również aktywność turystyczną.

Spośród naturalnych środowisk wychowawczych jako zmienną wybrano rodzinę przedstawiono jej wpływ na aktywność turystyczną badanych. Rodzina stanowi pierwsze i podstawowe środowisko, w którym dziecko może spotkać się z ofertą turystyczną. Dzieje się to głównie za pomocą modelowania, a więc dawania własnego przykładu. Stosunek rodziców do pracy, wypoczynku, rozwoju i rozrywki może uświadomić dzieciom, że czas wolny jest ważną rzeczą. Rodzice jako osoby odpowiedzialne za kształtowanie osobowości swoich dzieci starają się, na miarę swojej wiedzy i przygotowania, stworzyć im odpowiednie warunki do wypoczynku oraz pobudzać je do aktywności turystycznej. Poniesiony trud rodzicielski powoduje, że młody człowiek, wzrastając w określonym środowisku, nabiera charakterystycznych dla tego środowiska doświadczeń. Doświadczenia te z kolei kształtują jego zachowania i zainteresowania. Bywa też tak, że rodzice nie potrafią lub nie chcą zadbać o wykształcenie wzorów i umiejętności wartościowego wykorzystania czasu wolnego u swoich podopiecznych. Skutki takiego modelu działania mogą być dość ryzykowne, ponieważ nieodpowiednio zagospodarowany czas wolny młodego człowieka w przyszłości może mu wyznaczyć inną rzeczywistość, inne miejsce w społeczeństwie, inną karierę zawodową, inną jakość $\dot{z ̇ y c i a}^{21}$.

Kamiński $^{22}$ wielokrotnie podkreślał, że kierunek aktywności w czasie wolnym nadaje rodzina, a czynnikiem kształtującym wzory spędzania czasu wolnego jest przykład rodziców. Od postępowania rodziców w dużym stopniu będzie zależało, czy ich dzieci będą uprawiały turystykę i jaki będzie jej poziom. Czynnik ten jest lekceważony i często niedostrzegany, jak zauważa Różycki ${ }^{23}$. W tabeli 1 sprawdzono, czy reguła ta odnosi się również do grupy badanych studentów.

\footnotetext{
${ }^{19}$ A. Kamiński, Funkcje pedagogiki społecznej, Wydawnictwo Naukowe PWN, Warszawa 1980; J. Pięta, Pedagogika czasu wolnego, Wydawnictwo WSE, Warszawa 2004.

${ }^{20}$ J. Pięta, op. cit.

21 A. Delekta, Czas wolny młodzieży jako kategoria kształtowania zasobów ludzkich, „Problemy Współczesnego Zarządzania” 2009/2.

22 A. Kamiński, $O$ wczasach petnych $i$ wychowawczo poprawnych, „Problemy OpiekuńczoWychowawcze" 1971/3.

${ }^{23}$ P. Różycki, op.cit.
} 
Tabela 1. Aktywność turystyczna $\mathrm{z}$ rodzicami w przeszłości a uczestnictwo w wyjazdach turystycznych w ciagu ostatniego roku (z co najmniej jednym noclegiem)

\begin{tabular}{|c|c|c|c|c|c|c|c|c|}
\hline \multirow{3}{*}{$\begin{array}{l}\text { Rodzice zabierali mnie poza } \\
\text { stałe miejsce pobytu w celach } \\
\text { turystycznych }\end{array}$} & \multicolumn{8}{|c|}{$\begin{array}{l}\begin{array}{l}\text { Aktywność turystyczna w ostatnim roku } \\
\text { (z noclegiem) }\end{array} \\
\end{array}$} \\
\hline & \multicolumn{2}{|c|}{ Brak } & \multicolumn{2}{|c|}{$\begin{array}{l}\text { 1-2 } \\
\text { wyjazdy }\end{array}$} & \multicolumn{2}{|c|}{$\begin{array}{l}\text { Wiele } \\
\text { wyjazdów }\end{array}$} & \multicolumn{2}{|c|}{ Ogółem } \\
\hline & $\mathrm{N}$ & $(\%)$ & $\mathrm{N}$ & $(\%)$ & $\mathrm{N}$ & $(\%)$ & $\mathbf{N}$ & $(\%)$ \\
\hline Bardzo często & 3 & 3,8 & 26 & 33,4 & 49 & 62,8 & 78 & 17,8 \\
\hline Często & 8 & 4,3 & 78 & 41,9 & 100 & 53,8 & 186 & 42,5 \\
\hline Rzadko & 10 & 6,7 & 83 & 55,7 & 56 & 37,6 & 149 & 34,0 \\
\hline Wcale & 7 & 28,0 & 5 & 20,0 & 13 & 52,0 & 25 & 5,7 \\
\hline Ogółem & 28 & 6,4 & 192 & 43,8 & 218 & 49,8 & 438 & 100 \\
\hline Test chi ${ }^{2}$ & \multicolumn{8}{|c|}{$\mathrm{df}=6, \mathrm{p}<0,001$} \\
\hline
\end{tabular}

Źródło: opracowanie własne na podstawie przeprowadzonych badań.

Tak jak przewidywano, aktywność turystyczna studentów zależy od tego, czy i jak często badani wyjeżdżali w przeszłości wspólnie $\mathrm{z}$ rodzicami $\mathrm{w}$ celach turystycznych. Wiele razy w ciągu roku wyjeżdżają ci studenci, którzy deklarowali, że w przeszłości wyjeżdżali wraz z rodzicami „często” lub „bardzo często”. Spośród badanych krakowskiego ośrodka akademickiego aż 62,8\% studentów z grupy „wyjeżdżających z rodzicami bardzo często" wyjeżdża obecnie wielokrotnie w ciągu roku. Badania wskazują również, że studenci, którzy obecnie nie są aktywni turystycznie, w przeszłości nie wyjeżdżali wraz z rodzicami poza swoje stałe miejsce pobytu w celach turystycznych lub wyjazdy takie były sporadyczne.

Na podstawie analizy statystycznej stwierdzono, że poziom istotności statystycznej $p$ jest mniejszy niż 0,001 dla analizowanych zmiennych. W badaniach wykazano statystycznie istotną zależność pomiędzy aktywnością turystyczną odbywaną w przeszłości z rodzicami a częstością wyjazdów badanych (w dorosłym życiu) z minimum jednym noclegiem w ciągu roku poprzedzającego termin badań (tab. 1).

Ciekawa wydaje się też kwestia zaangażowania dziecka w przygotowanie się do wyjazdu rodzinnego. Postawiono pytanie, czy partycypowanie dziecka w przygotowaniu wyjazdu, oddanie mu części obowiązków sprawi, że młody człowiek zainteresuje się turystyką, że w przyszłości stanie się bardziej aktywny niż jego rówieśnicy, którzy takiego przywileju nie doświadczyli? Wydaje się, że odpowiedzi na te pytania dostarczają dane przedstawione $\mathrm{w}$ tabeli 2 . Wśród studentów krakowskiego ośrodka akademickiego obserwuje się zależność między partycypowaniem w przygotowywaniu wyjazdów turystycznych wraz z rodzicami w przeszłości a ich obecnym poziomem aktywności turystycznej. Studenci, którzy jako dzieci i młodzież byli angażowani w przygotowanie wyjazdu rodzinnego o charakterze turystycznym, częściej od pozostałych uprawiają turystykę $(\mathrm{p}<0,001)$. 
Tabela 2. Pomoc rodzicom w przygotowaniu wyjazdów turystycznych w przeszłości a aktywność turystyczna w ciągu ostatniego roku (z co najmniej jednym noclegiem)

\begin{tabular}{|c|c|c|c|c|c|c|c|c|}
\hline \multirow{3}{*}{$\begin{array}{l}\text { Pomagałam/pomagałem } \\
\text { w przygotowaniu } \\
\text { wyjazdu rodzinnego }\end{array}$} & \multicolumn{2}{|c|}{$\begin{array}{l}\text { Aktywność } \\
\text { (z noclegiem) }\end{array}$} & \multicolumn{2}{|c|}{ turystyczna } & w & \multicolumn{2}{|c|}{ ostatnim } & \multirow[t]{2}{*}{ roku } \\
\hline & \multicolumn{2}{|c|}{$\begin{array}{l}\text { Nie } \\
\text { wyjeżdżam }\end{array}$} & \multicolumn{2}{|c|}{$\begin{array}{l}\text { 1-2-krotnie } \\
\text { w ciągu } \\
\text { roku }\end{array}$} & \multicolumn{2}{|c|}{$\begin{array}{l}\text { Wielokrotnie } \\
\text { w ciągu roku }\end{array}$} & Ogółem & \\
\hline & $\mathrm{N}$ & $(\%)$ & $\mathrm{N}$ & $(\%)$ & $\mathrm{N}$ & $(\%)$ & $\mathbf{N}$ & $(\%)$ \\
\hline Tak & 4 & 4,1 & 31 & 32,0 & 62 & 63,9 & 97 & 22,1 \\
\hline Raczej tak & 6 & 2,6 & 113 & 49,6 & 109 & 47,8 & 228 & 52,1 \\
\hline Raczej nie & 3 & 3,8 & 41 & 51,2 & 36 & 45,0 & 80 & 18,3 \\
\hline $\mathrm{Nie}$ & 9 & 27,3 & 11 & 33,3 & 13 & 39,4 & 33 & 7,5 \\
\hline Ogółem & 22 & 5,0 & 196 & 44,7 & 220 & 50,3 & 438 & 100 \\
\hline Test chi ${ }^{2}$ & \multicolumn{8}{|c|}{$\mathrm{Df}=6, \mathrm{p}<0,001$} \\
\hline
\end{tabular}

Źródło: opracowanie własne na podstawie przeprowadzonych badań.

Nie bez znaczenia dla kształtowania się zainteresowań turystycznych jest oddziaływanie szkoły. Szkoła jako intencjonalne środowisko wychowawcze podejmuje wiele działań mających na celu wychowanie uczniów do wartościowego wykorzystania czasu wolnego przez aktywność turystyczną. Szkoła może ten cel realizować zarówno w czasie zajęć przedmiotowych, jak i w ramach zajęć pozalekcyjnych. Istotna jest tutaj działalność Szkolnych Kół Krajoznawczo-Turystycznych PTTK. Warto w tym miejscu zwrócić uwage na to, że uczestnictwo w turystyce wyrabia u dzieci i młodzieży spostrzegawczość, kształci uwagę, rozwija myślenie oraz budzi pozytywne uczucia w stosunku do otoczenia przyrodniczego i społecznego. Kontakt $\mathrm{z}$ naturą pomaga w rozwinięciu przyjacielskiego i świadomego stosunku człowieka do świata przyrody. Taki kontakt gwarantują wycieczki szkolne, rajdy, wszelkiego rodzaju zajęcia terenowe i geograficzne, a częściowo również zielone szkoły. Oprócz tego dzięki wycieczkom dzieci w przystępny i obrazowy sposób poznają otaczający je świat. Możliwości kształtowania postaw turystycznych przez szkołę były podejmowane między innymi przez Kamińskiego $^{24}$, Woźniaka ${ }^{25}$, Denka ${ }^{26}$ i innych.

Korzyści płynących z uprawiania turystyki za pośrednictwem szkoły jest wiele (jak już pokazano). Pojawiają się jednak pytania: czy szkoła jako najmocniejsza placówka oświatowo-wychowawcza w środowisku lokalnym rzeczywiście kreuje i pomaga planować czas wolny uczniów, aby ci przeznaczali go na aktywność turystyczną i

\footnotetext{
${ }^{24}$ A. Kamiński, Czas wolny i jego problematyka społeczno-wychowawcza, Zakład Narodowy im. Ossolińskich, Wrocław 1965; idem, Nauczanie $i$ wychowanie metoda harcerska, Związek Harcerstwa Rzeczypospolitej, Warszawa 2001.

${ }^{25}$ E. Woźniak, Pedagogika czasu wolnego Aleksandra Kamińskiego, [w:] Koncepcja czasu wolnego Aleksandra Kamińskiego, red. M. Walczak, Wydawnictwo WSP, Zielona Góra 1996.

${ }^{26}$ K. Denek, op. cit.
} 
rekreacyjną? Czy jest swoistym terenowym centrum, które nie tylko kształci, ale i umożliwia dzieciom i młodzieży realizację ich potrzeb i zainteresowań, również tych związanych z turystyką? Jak działalność szkoły w zakresie rozbudzania zainteresowania turystyką przez organizowanie wycieczek oceniają sami jej uczniowie? Zapytano badanych studentów, jak często (przeciętnie) szkoły, do których uczęszczali, organizowały ich klasom wyjazdy w celach turystycznych w ciagu roku. Odpowiedzi na to pytanie zestawiono $\mathrm{z}$ odpowiedziami na pytanie o wyjazdy turystyczne $\mathrm{z}$ minimum jednym noclegiem w roku poprzedzającym termin badań (tab. 3) i sprawdzono, czy częstość wyjazdów turystycznych z klasą szkolną i zaangażowanie szkoły w działalność turystyczną mogły wpłynąć na poziom aktywności turystycznej badanych.

Tabela 3. Turystyka szkolna a uczestnictwo w wyjazdach turystycznych studentów w ciagu ostatniego roku (z co najmniej jednym noclegiem)

\begin{tabular}{|c|c|c|c|c|c|c|c|c|}
\hline \multirow{3}{*}{$\begin{array}{l}\text { Szkoła organizowała mojej } \\
\text { klasie wyjazd (średnio w ciągu } \\
\text { roku) }\end{array}$} & \multicolumn{8}{|c|}{$\begin{array}{l}\text { Aktywność turystyczna w ostatnim roku } \\
\text { (z noclegiem) }\end{array}$} \\
\hline & \multicolumn{2}{|c|}{ Brak } & \multicolumn{2}{|c|}{$\begin{array}{l}\text { 1-2 } \\
\text { wyjazdy }\end{array}$} & \multicolumn{2}{|c|}{$\begin{array}{l}\text { Wiele } \\
\text { wyjazdów }\end{array}$} & \multicolumn{2}{|c|}{ Ogółem } \\
\hline & $\mathrm{N}$ & $(\%)$ & $\mathrm{N}$ & $(\%)$ & $\mathrm{N}$ & $(\%)$ & $\mathbf{N}$ & $(\%)$ \\
\hline Kilkakrotnie & 13 & 6,7 & 68 & 35,3 & 112 & 58,0 & 193 & 44,0 \\
\hline Raz na rok & 24 & 13,0 & 63 & 34,3 & 97 & 52,7 & 184 & 42,0 \\
\hline Raz na kilka lat & 3 & 5,5 & 26 & 47,2 & 26 & 47,3 & 55 & 12,6 \\
\hline Wcale & 2 & 33,3 & 3 & 50,0 & 1 & 16,7 & 6 & 1,4 \\
\hline Ogółem & 42 & 9,6 & 160 & 36,5 & 236 & 53,9 & 438 & 100 \\
\hline Test chi $^{2}$ & \multicolumn{8}{|c|}{$\mathrm{df}=6, p=0,036$} \\
\hline
\end{tabular}

Źródło: opracowanie własne na podstawie przeprowadzonych badań.

Wartość poziomu istotności statystycznej pozwala mówić o istnieniu zależności między analizowanymi zmiennymi w badanej populacji $(\mathrm{p}=0,036)$.

\footnotetext{
6. PRZYNALEŻNOŚĆ DO ORGANIZACJI TURYSTYCZNYCH A AKTYWNOŚĆ TURYSTYCZNA

W niniejszej pracy wspominano, że aktywność turystyczna młodzieży kształtowana jest przede wszystkim za pośrednictwem rodziny, szkoły i organizacji społecznych. W tej części pracy przedstawiono analizę tego ostatniego czynnika, czyli organizacji społecznych, a w szczególności tych, które prowadzą działalność turystyczną. Badania na temat roli organizacji społecznych w kształtowaniu aktywności turystycznej prowadziła też Wartecka-Ważyńska ${ }^{27}$. Badaną zbiorowością była grupa młodzieży szkół ponadgimnazjalnych województwa wielkopolskiego (próba badawcza liczyła 666 osób).
}

\footnotetext{
${ }^{27}$ A. Wartecka-Ważyńska, op. cit.
} 
Autorka ta do najważniejszych organizacji społecznych wpływających na udział młodzieży w turystyce zaliczyła: ZHP, PTTK i organizacje kościelne, i skupiła się szczególnie na analizie tych ostatnich.

$\mathrm{Na}$ podstawie przeprowadzonych badań stwierdzono, że w krakowskim ośrodku akademickim do organizacji turystycznych należało $15 \%$ studentów, w tym $8 \%$ do PTTK $^{28}$. Studenci zgłaszali także przynależność do innych organizacji, których działalność związana była z turystyką. Były to organizacje kościelne, stowarzyszenia oraz Związek Harcerstwa Polskiego i Związek Harcerstwa Rzeczypospolitej. Na podstawie analizy statystycznej zebranych danych można stwierdzić występowanie statystycznie istotnej zależności między przynależnością studentów do organizacji o charakterze turystycznym a aktywnością turystyczną w ciągu roku poprzedzającego termin badań. Dla analizowanych zmiennych ,p” przyjmuje bardzo małą wartość $(<0,001)$. Należy zatem odrzucić hipotezę zerową (Ho) mówiącą o braku jakichkolwiek zależności pomiędzy przynależnością studentów do organizacji turystycznych a ich uczestnictwem w wyjazdach turystycznych w ciągu roku bezpośrednio poprzedzającego termin wykonania badań. Wartości zawarte w tabeli 4 potwierdzają słuszność tego stwierdzenia.

Tabela 4. Wpływ przynależności studenta do organizacji o charakterze turystycznym na uczestnictwo w wyjazdach turystycznych w ciagu ostatniego roku (z co najmniej jednym noclegiem)

\begin{tabular}{|c|c|c|c|c|c|c|c|c|}
\hline \multirow{3}{*}{$\begin{array}{l}\text { Przynależność do organizacji } \\
\text { turystycznej }\end{array}$} & \multicolumn{8}{|c|}{$\begin{array}{l}\text { Aktywność turystyczna w ostatnim roku } \\
\text { (z noclegiem) }\end{array}$} \\
\hline & \multicolumn{2}{|c|}{ Brak } & \multicolumn{2}{|c|}{$\begin{array}{l}1-2 \\
\text { wyjazdy }\end{array}$} & \multicolumn{2}{|c|}{$\begin{array}{l}\text { Wiele } \\
\text { wyjazdów }\end{array}$} & \multicolumn{2}{|c|}{ Ogółem } \\
\hline & $\mathrm{N}$ & $(\%)$ & $\mathrm{N}$ & $(\%)$ & $\mathrm{N}$ & $(\%)$ & $\mathbf{N}$ & $(\%)$ \\
\hline Tak & 5 & 7,5 & 15 & 22,4 & 47 & 70,1 & 67 & 15,3 \\
\hline Nie & 42 & 11,3 & 192 & 51,8 & 137 & 36,9 & 371 & 84,7 \\
\hline Ogółem & 47 & 10,7 & 207 & 47,3 & 184 & 42,0 & 438 & 100 \\
\hline Test chi ${ }^{2}$ & \multicolumn{8}{|c|}{ df $=2, p<0,001$} \\
\hline
\end{tabular}

Źródło: opracowanie własne na podstawie przeprowadzonych badań.

\section{PODSUMOWANIE}

W pracy postanowiono zweryfikować hipotezę o wpływie niektórych czynników o charakterze społecznym na aktywność turystyczną studentów krakowskiego ośrodka akademickiego. Analizom poddano takie czynniki społeczne jak: przynależność studenta do organizacji o charakterze turystycznym, częstość wyjazdów turystycznych z rodzicami i udział badanego w przygotowaniu wyjazdu rodzinnego oraz częstość wyjazdów

\footnotetext{
${ }^{28}$ Polskie Towarzystwo Turystyczno-Krajoznawcze jest organizacją społeczną, która powstała w 1950 r. z połączenia Polskiego Towarzystwa Tatrzańskiego (1873) oraz Polskiego Towarzystwa Krajoznawczego (1906), czyli organizacji tworzących polskie krajoznawstwo.
} 
turystycznych z klasą szkolną (przed podjęciem studiów). Zastosowany test chi-kwadrat $\left(\mathrm{chi}^{2}\right)$ dostarczył informacji o tym, że wszystkie analizowane zmienne wykazały istotne statystycznie zależności z uczestnictwem studentów w turystyce.

Aby określić siłę identyfikowanych zależności, wykorzystano współczynnik zbieżności T-Czuprowa. Wartości, jakie uzyskano, pozwalają na stwierdzenie, że w krakowskim ośrodku akademickim najsilniejszy wpływ na aktywność turystyczną studentów miała częstość wyjazdów turystycznych z rodzicami.

Można zatem przyjąć hipotezę H1 mówiącą o tym, że istnieje istotna zależność między wybranymi czynnikami społecznymi a poziomem aktywności turystycznej studentów krakowskiego ośrodka akademickiego. Należy również zauważyć, że tradycje domu rodzinnego w zakresie spędzania czasu wolnego determinują w sposób szczególny poziom uczestniczenia w turystyce przez studentów.

\section{LITERATURA}

[1] Alejziak W., Determinanty i zróżnicowanie społeczne aktywności turystycznej, Wydawnictwo AWF, Kraków 2009.

[2] Bomirska L., Gawlak-Kica G., Kraśnicki E., Społeczno-ekonomiczne bariery uczestnictwa młodzieży szkolnej $i$ studiujacej $w$ turystycznych formach rekreacji, [w:] Wyznaczniki i bariery uczestnictwa $w$ turystycznych formach rekreacji, red. S. Wykrętowicz, Wydawnictwo AWF, Warszawa 1988.

[3] Boyer M., Le tourisme, Presses Universitaires de Lyon, Lyon 1999.

[4] Delekta A., Czas wolny młodzieży jako kategoria ksztattowania zasobów ludzkich, „Problemy Współczesnego Zarządzania” 2009/2.

[5] Denek K., W kręgu edukacji, krajoznawstwa i turystyki w szkole, Eruditus, Poznań 2000.

[6] Jedlińska M., Specyfika zachowań konsumenckich na rynku turystycznym, [w:] Turystyka $w$ badaniach naukowych, red. A. Nowakowska, M. Przydział, Prace ekonomiczne, WSiZ, Rzeszów 2006.

[7] Kaczmarek J., Stasiak A., Włodarczyk B., Produkt turystyczny albo jak organizować poznawanie świata, Wydawnictwo Uniwersytetu Łódzkiego, Łódź 2002.

[8] Kamiński A., Nauczanie i wychowanie metoda harcerska, Związek Harcerstwa Rzeczypospolitej, Warszawa 2001.

[9] Kamiński A., Funkcje pedagogiki społecznej, Wydawnictwo Naukowe PWN, Warszawa 1980.

[10] Kamiński A., O wczasach petnych $i$ wychowawczo poprawnych, „Problemy Opiekuńczo-Wychowawcze" 1971/3.

[11] Kamiński A., Czas wolny i jego problematyka społeczno-wychowawcza, Zakład Narodowy im. Ossolińskich, Wrocław 1965.

[12]Łopaciński K., Poziom aktywności turystycznej studentów, [w:] Społecznopedagogiczne problemy turystyki, red. J.A. Malinowski, Instytut Turystyki, Warszawa 1988.

[13] Łopaciński K., Aktywność turystyczna młodzieży akademickiej, „Problemy Turystyki" 1986/2.

[14] Marcinkowski M., Zachowania wolnoczasowe wskaźnikiem jakości życia, [w:] Czas wolny. Rekreacja. Turystyka. Hotelarstwo. Żywienie, red. W. Siwiński, 
R.D. Tauber, E. Mucha-Szajek, Wydawnictwo Wyższej Szkoły Hotelarstwa i Gastronomii w Poznaniu, Poznań 2003.

[15] Pięta J., Pedagogika czasu wolnego, Wydawnictwo WSE, Warszawa 2004.

[16]Różycki P., Determinanty aktywności turystycznej młodzieży, „Problemy Turystyki" 2006/1-4.

[17] Skorny Z., Mechanizmy regulacyjne ludzkiego działania, Wydawnictwo Naukowe PWN, Warszawa 1989.

[18] Wartecka-Ważyńska A., Turystyka młodzieży $i$ jej uwarunkowania, Wydawnictwo Naukowe UAM, Poznań 2007.

[19] Wartecka-Ważyńska A., Rola wybranych organizacji społecznych w kształtowaniu aktywności turystycznej młodzieży, "Turystyka i Hotelarstwo" 2005/8.

[20] Woźniak E., Pedagogika czasu wolnego Aleksandra Kamińskiego, [w:] Koncepcja czasu wolnego Aleksandra Kamińskiego, red. M. Walczak, Wydawnictwo WSP, Zielona Góra 1996.

[21]Zawadzki M., Metody badania uczestnictwa mieszkańców Polski w podróżach, „Problemy Turystyki” 1993/3.

\section{SOCIAL DETERMINANTS OF TOURISM ACTIVITY OF CRACOW}

UNIVERSITIES' STUDENTS

The article discusses the problems of tourist activity that takes an important place among the studies that aimed at understanding the rules and mechanisms governing the tourist market. A short review of current classifications of determinant groups of tourist activity was made to point out the most important exogenous factors (economic, demographic and social).

The purpose of this study was to determine the influence of social factors on the student's tourism activity level. An analysis was made against the influence of family, school and some tourist organizations the examined student belonged to. In particular, an interesting questions was to find out whether the practice of tourism with their parents in childhood and adolescence determines its level of tourism activity in adulthood. It's been hypothesized (H1) on the existence of a significant relationship between selected social factors and the level of tourist activity among the students of Cracow Universities. The study was conducted using the method of diagnostic survey. Randomly selected, full-time, second year students took part in the questionnaire that was prepared for data collecting (438 students in total). Statistical analysis based on the statistical methods like chi-square test, Tschuprow's $\mathrm{T}$ factor was used for calculations and for presenting associations and regularities found for given population.

Research has shown that social factors play a significant role in the process of tourist activity formation and the actual participation in the tourist activity for the students at given age range. Test results also help to identify the influence of the frequency of tourist trips with the parents as the strongest factor among the presented social factors.

Keywords: student tourism, tourism activity, social determinants of tourism activity, students.

DOI:10.7862/rz.2014.hss.54

Przesłano do redakcji: październik 2014

Przyjęto do druku: grudzień 2014 